\title{
水中誘起フェムト秒レーザー衝撃力により顕在化される細胞構造の差異
}

\author{
細川陽一郎 ${ }^{1}$, 吹田 啓介 ${ }^{1}$ ，米田 新 ${ }^{2}$ ，出村 拓 ${ }^{2}$ \\ '奈良先端科学技術大学院大学 物質創成科学研究科 ( ₹ 630-0192 奈良県生駒市高山町8916-5) \\ 2奈良先端科学技術大学院大学バイオサイエンス研究科( T 630-0192 奈良県生駒市高山町8916-5)
}

\section{Difference of Mechanical Structure of Cell Revealed by Femtosecond Laser-Induced Impulsive Force in Water}

\author{
Yoichiroh HOSOKAWA ${ }^{1}$, Keisuke FUKITA ${ }^{1}$, Arata YONEDA ${ }^{2}$, and Taku DEMURA ${ }^{2}$ \\ ${ }^{1}$ Graduate School of Materials Science, Nara Institute of Science and Technology, 8916-5 Takayama, Ikoma, Nara $630-0192$ \\ ${ }^{2}$ Graduate School of Biological Sciences, Nara Institute of Science and Technology, 8916-5 Takayama, Ikoma, Nara $630-0192$
}

(Received January 10, 2017)

\begin{abstract}
When an intense infrared femtosecond laser is focused inside an aqueous solution through an objective lens, shock and stress waves are generated at the laser focal point after effective multi-photon and excited-state absorptions. These waves propagate from the laser focal point and act in its vicinity with biological cells as an impulsive force, which we applied to manipulate animal and plant cells. In this review, we explained a photo-excitation mechanism at the laser focal point and indicated an advantage of the femtosecond laser-induced impulsive force in comparison with other pulse lasers. We observed the behaviors of animal and plant cells with impulsive force action by high-speed imaging and interpreted their differences from the mechanism to protect the cell from external force.
\end{abstract}

Key Words: Laser-manipulation, Laser-induced shockwave, Bio-application, Animal cell, Plant cell, Protoplast

1.はじめに

高強度の近赤外フェムト秒レーザーを顕微鏡下で水溶 液に集光照射すると，集光点で爆発現象が誘導され，そ の周囲に衝撃波と応力波が伝搬する。我々は, この衝撃 波と応力波を, 単一細胞に撃力(衝撃力) として作用さ せ，これまで難しかった新しい細胞操作を多数提案して きている1．例えば, この衝撃力を用いることにより， 細胞培養基板に接着した標的細胞を一つずつ引きはがし たり，接着した細胞同士を乘離させたりできることを報 告している2-6)。これまでに，レーザートラッピング(光 ピンセット)を用いて単一の細胞を高度に制御すること が試みられているが，その力(光の放射圧)は弱く，これ らの操作は難しい文。、イクロマニピュレーターや原子 間力顕微鏡を用いた，細胞操作についても報告されてい るが8)，操作には熟練の技術を要する。またこの様な細 胞培養液に器具を挿入するこれらの方法では, 貴重な細 胞試料を污染する危険性がある。我々が開発を進めてい るフェムト秒レーザー誘起衝撃力を利用した方法は, 非 接触に強い力で細胞を個別に操作できる点で, 従来法を 凌駕しており，生物学・医学分野において期待されてい る。
本稿では，まずこれまでに推測されている透明材料に 対する高強度レーザーパルスの吸収過程について解説 し，フェムト秒レーザーが，ナノ秒レーザーやピコ秒 レーザーなどの他のパルスレーザーに比べて細胞を操作 する上で適している理由を述べる。次に，動物細胞や植 物細胞に対して衝撃力が作用したときの細胞の挙動を高 速カメラにより観察した結果を示し, 動物細胞と植物細 胞の機械的な構造の差異について述べ，その違いについ て, 動物と植物の外力に対する防御機能の違いから推測 する。

\section{2. フェムト秒レーザーパルスの吸収過程}

水や生体材料に透過性の高い $800 \mathrm{~nm}$ のフェムト秒 レーザー光を，顕微鏡下で水溶液に集光照射すると，集 光点でレーザー光が吸収され，衝撃波と応力波が発生す る(Fig. 1).ささらに衝撃波と応力波の伝搬に伴う圧力低 下が主原因と考えられる急激な気化が集光点で誘導さ れ，キャビテーションバブルと呼ばれる気泡が生成され る。これらの現象を誘導するために必要となるレーザー パルスエネルギーはレーザーの集光角(対物レンズの開 口数)に大きく依存するために一概には言えないが, 


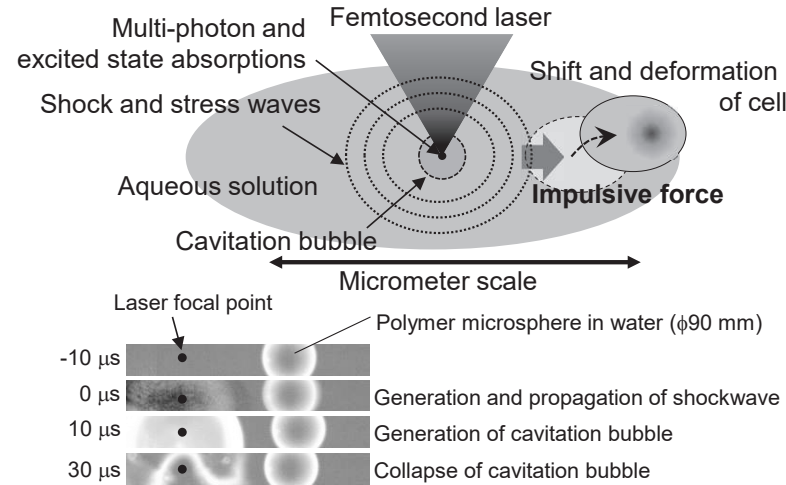

Fig. 1 Phenomena induced by focusing femtosecond laser pulse inside water. Shock and stress waves are generated at the laser focal point and propagates with cavitation bubble generation

数 $\mathrm{nJ}$ から数 $10 \mu \mathrm{J} / \mathrm{pulse}$ 程度である. 生体材料の主成分で ある水の吸収端は200 $\mathrm{nm}$ 程度であり，このレーザーパ ルスで4光子以上の高次の多光子吸収過程が集光点で引 き起こされる. この場合, 水の光吸収はレーザーのパル スエネルギーに対して4次以上の非線形性を持つと思わ れるが, 実際に見られる衝撃波, 応力波, キャビテー ションバブルの発生は，そのようなべき乗に比例するよ うな強いパルスエネルギー依存性は示さず, これらの発 生しきい值以上でほぼ線形的に増加する傾向を示す.

Fig. 2 に実験結果から考えられるフェムト秒レーザー の光吸収過程を示す。前述のとおり, 水への光吸収の始 まりは, 電子基底状態から電子励起状態への4光子以上 の多光子吸収過程で誘導されるが, 入射したフェムト秒 レーザーパルスの前半部分で高密度な電子励起状態が生 成され, 集光点でこの過程は飽和すると考えられる。電 子励起状態では励起エネルギー準位が密に存在するた め，入射したレーザーパルスの後半部分は電子励起状態 で1光子吸収過程により吸収されると考えられる。また, 高い電子励起状態から低い電子励起状態へのエネルギー

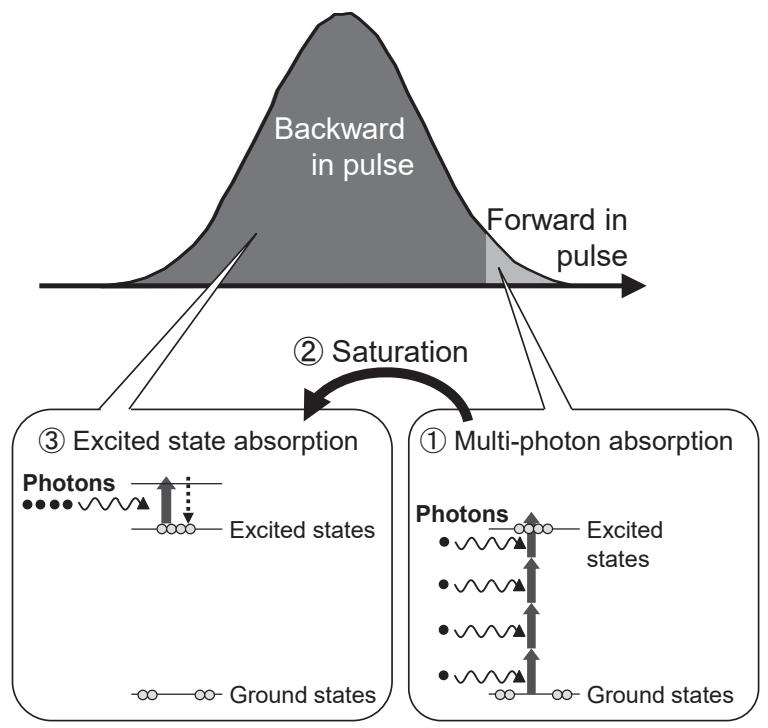

Fig. 2 Absorption processes induced at the laser focal point into water by an intense femtosecond laser pulse with wavelength of $800 \mathrm{~nm}$.
緩和は極めて速いことが知られており，低い電子励起状 態と高い電子励起状態の間で吸収が繰り返され，電子励 起状態では吸収飽和は起こらず，入射パルスの後半部分 は線形的に吸収されると考えられる。

光化学に基づく分子の概念を否定しない説明は上記の とおりとなるが，水を半導体と近似し，多光子吸収によ りパルスの前半部でプラズマ状態が生成し，プラズマ状 態による吸収でパルスの後半部で光が線形的に吸収され るモデルでも説明されている9 .

このような吸収過程では, 衝撃波, 応力波, キャビ テーションバブルの発生しきい值は, 4光子吸収過程が 誘導されるレーザーパルスの強度 (尖頭值)に依存し, 引 き起こされる現象の大きさはレーザーパルスエネルギー に比例する。これまでの研究で, 原子間力顕微鏡 (AFM)の探針に作用する衝撃力の大きさのレーザーパ ルスエネルギーについて調べており，上記の過程で説明 できる依存性を示している.

近赤外のナノ秒パルスを顕微鏡下で集光した場合，衝 撃波, 応力波, キャビテーションバブルの発生しきい值 となるレーザーパルスエネルギーは千倍以上に上昇し， これらの現象の規模はフェムト秒パルスによるものより も遥かに大きくなり，Fig. 2 に示す過程で同様に説明で きる。結果として，フェムト秒レーザーを10倍から 100 倍の対物レンズで集光した場合，衝撃波，応力波の伝搬 範囲とキャビテーションバブルの大きさは, $1 \mu \mathrm{m}$ から 数10 $\mu \mathrm{m}$ の精度で自在に制御できる。しかし，ナノ秒 レーザーではこれらの現象を顕微鏡下で制御することは できない.

細胞の大きさは，一般に数 $\mu \mathrm{m}$ から数 $10 \mu \mathrm{m}$ であり, 顕微鏡下で制卸できるフェムト秒レーザー誘起衝撃力 の作用範囲とほぼ同等のサイズである。我々がこれま でに示してきたフェムト秒レーザー誘起衝撃力による 細胞操作は, 前項で示した水に対するフェムト秒レー ザーパルスの多光子吸収過程と励起状態吸収過程の適 度なバランスが存在することを偶然に発見し，実現し たと言える。

\section{3.レーザー誘起衝撃力による細胞変形と移動}

フェムト秒レーザー衝撃力による細胞操作において, 衝撃力により細胞に如何なる力学的・生理的作用がもた らされるかは本質的な問題である。我々はこれまでに, 動物細胞, 植物細胞, 微生物などの様々な試料について 検討を進め，これらの作用が細胞の構造に大きく依存す ることを見出している，高等植物の細胞は，七ルロース を主成分とする細胞壁で覆われ，細胞内を陽圧にして細 胞を膨らみきった状態にし, 細胞壁の堅さにより細胞の 形状, さらには細胞が積み重なった個体の形状を支えて いる。このような植物の構造は, 骨格により構造を支え る動物とは根本的に異なっており，その違いは如実に細 胞構造の違いとして反映される。

ここでは，フェムト秒レーザー衝撃力の作用による培 養植物細胞と培養動物細胞の変形と移動を高速カメラに 
より観察した結果について紹介し, 細胞内の力学構造の 明瞭な違いについて示す。

\section{1 培養植物細胞}

ここではまず高等植物のモデル試料として広く用いら れているタバコBY-2細胞にフェムト秒レーザー誘起衝 撃力を作用させた結果について示す。この細胞は, 夕バ コの植物個体から単離された細胞の一種であり, 培養液 中にこの細胞を拡散させ，恒温で摇り動かしつづけるこ とで(浸とう培養することで)個体を形成することなく増 え続ける，植物細胞は周囲を細胞壁に覆われており，こ の細胞壁の特性を理解するため, 単糖であるマンニトー ルを培養液に添加することにより原形質分離を起こさ せ，細胞壁と細胞膜を分離させた。この培養液に拡散し たBY-2細胞をガラスボトムディッシュにとりわけ，顕 微鏡ステージに配置し, 細胞を観察するための対物レン

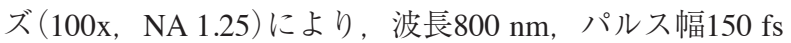
のフェムト秒レーザーパルスを細胞の横に集光した.

Fig. 3 にBY-2細胞の側方にフェムト秒レーザーを集光 した際にみられる細胞の変形と移動を高速カメラにより 観察した結果について示す。レーザー照射直後 $(0 \mu \mathrm{s})$ に 観察される白い影はキャビテーションバブルの生成に伴 う透過像の歪みによるものであり，レーザー集光点はそ の中心である。キャビテーションバブルの生成消滅速度 は, 高速カメラの時間分解能 $(5 \mu \mathrm{s})$ よりも短く, そのサ イズは撮像ごとに変動したが, 最大直径は60 $\mu \mathrm{m}$ 程度で あると見積もられる。：４ｓではこのキャビテーションバ ブルの衝突と同時にBY-2細胞の細胞壁が変形し収縮す る様子が観察されている。その後, 細胞の変形は解消さ

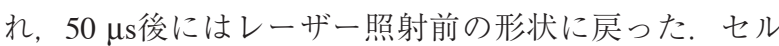
ロースを主成分とする細胞壁と水の界面には，大きな音 響インピータンスのミスマッチングがあり，細胞壁が衝 撃波を効率的に吸収し，さらには応力波の伝搬とキャビ テーションバブルの発生に伴うジェット流により細胞形 状に変形をもたらしたと考えられる。一方で, 細胞壁は 弾性を持っており破壊されず，50 $\mathrm{\mu}$ 後に元の形状に 戻ったと考えられる。

\section{2 プロトプラスト}

植物細胞の研究において, この細胞壁の堅牢な力学構 造が細胞内部の構造を理解したり, 操作したりする妨げ
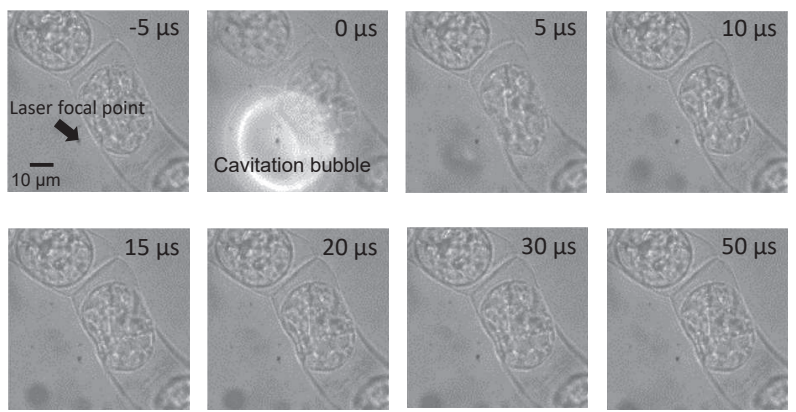

Fig. 3 Deformation of tobacco BY-2 cell. Pulse energy is $90 \mathrm{~nJ}$.
となる場合があり，酵素処理により細胞壁を取り除いた 細胞を実験試料として用いることがある。この細胞壁を 分解した細胞をプロトプラストという。プロトプラスト は，細胞壁の内側にある細胞膜のみで細胞構造を支え， 細胞内の陽圧も解消される。ここでは夕バコBY-2細胞 の細胞壁を，酵素であるセルラーゼ，ペクトリアーゼに より分解し, さらに陽圧の解消 (浸透圧の解消)によって 細胞が破裂しないように，細胞内の分子濃度と合わせる ために，単糖であるマンニトールを培養液に添加し，試 料として用いた。

Fig. 4 にタバコBY-2細胞のプロトプラストの側方に フェムト秒レーザー誘起衝撃力を作用させた結果につい て示す。衝撃力の作用直後にキャビテーションバブルに よってプロトプラストがわずかに押され，その5 $\mu \mathrm{s}$ 後に はキャビテーションバブルが崩壊し, それに伴いプロト プラストがレーザー集光点側に引き伸ばされ，10-30 $\mu \mathrm{s}$ 後にもとの球状に戻った。細胞膜は，脂質二重膜を主成 分としており，培養液との界面で，細胞壁のような大き な音響インピータンスのミスマッチングは無いと考えら れ, 細胞の移動と変形は, 衝撃波ではなく, 応力波と キャビテーションバブルの生成と崩壊に伴うジェット流 により引き起こされていると考えられる。ささらにー ザーパルスエネルギーが高いとき，レーザー集光点が細 胞に近接する場合，プロトプラストが衝撃力により破壊 される場合が増えた，Fig. 5 に示す結果では，キャビ テーションバブルによってプロトプラストが押し飛ばさ れた後, 細胞の一部が飛散し, 内部のオルガネラが膜の 外に流出している。これらの結果は, 細胞壁のない植物
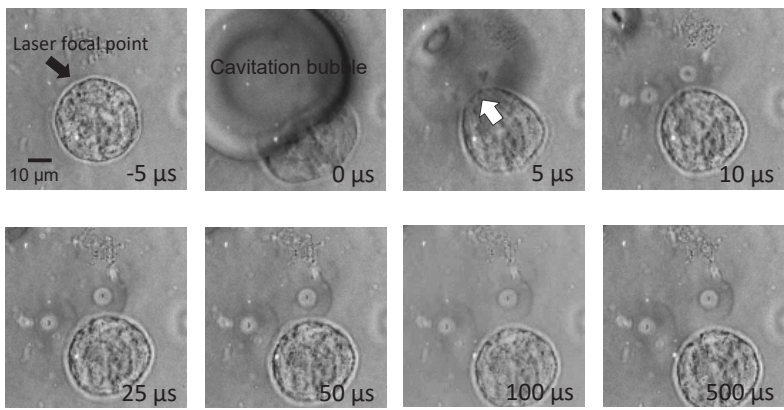

Fig. 4 Compression, elongation, and translational shift of protoplast of Tabaco BY-2 cell. Pulse energy is $90 \mathrm{~nJ}$.
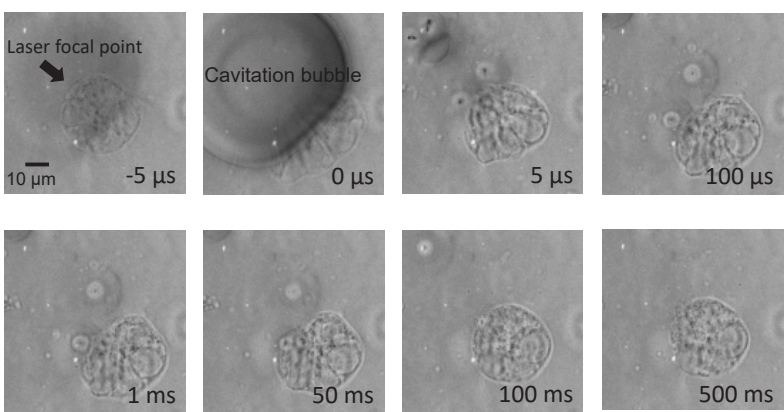

Fig. 5 Break of tobacco BY-2 protoplast. Pulse energy is $90 \mathrm{~nJ}$. 
細胞(プロトプラスト)が, 極めて力学的に脆弱であるこ とを示唆している.

\section{3 培養動物細胞}

動物細胞は植物細胞と異なり, 細胞壁を持たず, 細胞 膜のみによりその構造を維持している。ここでは動物細 胞の試料として, マウスの筋芽細胞株であるC $2 \mathrm{C} 12$ 細胞 を用いた。ディッシュ上で培養した $\mathrm{C} 2 \mathrm{C} 12$ 細胞をトリプ シンによって引きはがし，培養液中を浮遊する細胞の側 方にフェムト秒レーザーを集光照射した．細胞の大きさ は， 10-20 $\mu \mathrm{m}$ 程度でありBY-2細胞のプロトプラストの 半分程度である。

培養液中を浮遊する $\mathrm{C} 2 \mathrm{C} 12$ 細胞に, $\mathrm{BY}-2$ 細胞プロトプ ラストと同じレーザー照射条件で，レーザー誘起衝撃力 を作用させた結果をFig. 6 に示す。C2C12細胞では，プ ロトプラストのような, 細胞膜の伸縮, 破壊は観察され ず, 細胞の移動のみが観察された. C2C12細胞もBY-2細 胞プロトプラストと同様に細胞膜で覆われており, 細胞 への力学作用は衝撃波ではなく, 応力波とキャビテー ションバブルによるジェット流により誘導されると考え られる。C2C12細胞でBY-2細胞プロトプラストにみられ たような細胞形状の変形が観察されないことは, $\mathrm{C} 2 \mathrm{C} 12$ 細胞の細胞膜が, タバコBY-2細胞の細胞膜よりも剛性 が高く，弾性が低いことを示唆している。

\section{4. 細胞の堅さと機能}

本研究を通じて, 植物細胞は細胞壁により力学的な外 因から強く保護されており, 一方でその内部の細胞膜 は，極めて力学的に脆弱であることが分かった。一方 で, 動物細胞の細胞膜は, 植物細胞に比べて丈夫である ことが示唆された。動物細胞は, 細胞壁を持たない代わ りに, 細胞膜に構造を支えるタンパク質のネットワーク が張り巡らされていることが，明らかになってきてい る. それに対して植物細胞の構造上の力学特性は, この 様な動物細胞とは全く異なることが暗示される。

今後, フェムト秒レーザー誘起衝撃力が誘導する細胞 の変形挙動を高速撮影する実験に加え, 原子間力顕微鏡
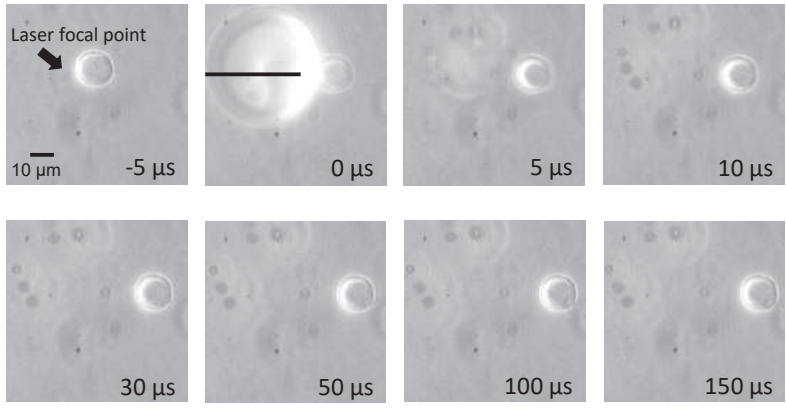

Fig. 6 Translational shift of mouse firebrat mouse skeletal muscle C2C12 cell. Pulse energy is $90 \mathrm{~nJ}$.

によりその変形挙動を定量化することにより，植物細胞 と動物細胞の力学特性, 環境応答特性を明らかにしてい きたいと考えている。

\section{謝 辞}

本研究は, 奈良先端科学技術大学院大学 物質創成科 学研究科細川研究室およびバイオサイエンス研究科出村 研究室の職員・学生諸氏のご協力により実現したもので あり，ここに深く感謝する。

\section{参考文献}

1) 細川 陽一郎：応用物理 82 (2012) 63.

2) Y. Hosokawa, J. Takabayashi, S. Miura, C. Shukunami, Y. Hiraki, and H. Masuhara: Appl. Phys. A 79 (2004) 795.

3) T. Kaji, S. Ito, H. Miyasaka, Y. Hosokawa, H. Masuhara, C. Shukunami, and Y. Hiraki: Appl. Phys. Lett. 91 (2007) 23904.

4) Y. Hosokawa, M. Hagiyama, T. Iino, Y. Murakami, and A. Ito: Proc. Natl. Acad. Sci. USA 108 (2011) 1777.

5) K. Oikawa, S. Matsunaga, S. Mano, M. Kondo, K. Yamada, M. Hayashi, T. Kagawa, A. Kadota, W. Sakamoto, S. Higashi, et al.: Nat. Plants 1 (2015) 15035.

6) T. Iino, M. Hagiyama, T. Furuno, A. Ito, and Y. Hosokawa: Biophys. J. 111 (2016) 2255.

7) 細川陽一郎, 高林 淳一, 宿南知佐, 開祐司, 増原宏: レーザー研究 32 (2004) 94.

8) O. Chaudhuri, S. H. Parekh, W. A. Lam, and D. A. Fletcher: Nat. Meth. 6 (2009) 383.

9) A. Vogel and V. Venugopalan: Chem. Rev. 103 (2003) 577. 